\title{
The Effects of Food Safety Knowledge, Attitude and Practices on Hotel Competitive Advantages: Perceptions of Food Service Staff in Hotels
}

\author{
Omar Qoura and EL Hussein Ali.
}

Faculty of Tourism and Hotels, Fayoum University

\begin{abstract}
The study aims to explore the effect of gained knowledge, attitudes and practices KAP of food safety among food and beverage department staff on hotels' competitiveness. Data were collected by a Semi-structured questionnaire distributed to food and beverage department staff at five-star hotels in Cairo. The obtained data were analysed using SPSS version 22.

The results reveal that food and beverage staff perceives the KAP variables to have a positive effect on hotels' reputation, cost savings, market share, and competitiveness of hotels.
\end{abstract}

Keywords: Knowledge, Attitude, Practices, KAP, Reputation, Competitiveness, Hotel, Egypt.

\section{Introduction}

Payne and Theis (2012) cleared that foodservice is unique in that it touches the lives of all of us on a daily basis. Food establishments can be found anywhere, including hotels, fast food outlets, hospitals, schools, universities, convenience stores, supermarkets, nursing homes, stadium concessions, child care and elder care, military bases, transport terminals, prisons, and so on (Garayoa et al., 2011). Kandampully, (2007) indicated that food industry is considered to be a large industry as it is made up of businesses that produce, manufacture, transport, and distribute food from farm to fork. With globalization, food service industry has developed enormously and the industry could prosper for its bottom line (Mcswane et al., 2004).

Greig et al., (2007) agreed with Jones and Angulo, (2006) that food-borne diseases have been increasing in the last years, with a greater effect on the health and economy of developing countries than developed countries (WHO, 2007). According to WHO report in 2005 alone, 1.8 million people died from diarrheal diseases and most of these cases were attributed to the ingestion of food and drinking contaminates water; each year roughly 1 out of 6 Americans (or 48 million people) gets sick, 128,000 are hospitalized, and 3,000 die from food borne diseases (http://homefoodsafety.org/food-poisoning/food-safety-facts: accessed in December 2014).And About $75 \%$ of the new infectious diseases affecting humans over the past 10 years were caused by bacteria, viruses and other pathogens that started in animals and animal products. Many of these diseases in people are related to the handling of infected domestic and wild animals during food production - in food markets and at slaughterhouses (http://www.who.int/features/factfiles/food_safety/facts/en/index3.html: accessed in December 2014). The prevalence of the bacteria in the population is so high that it is likely impossible to eliminate them. However, hand washing has been identified as one of the most important ways to prevent the spread of food-borne diseases (Clayton, and Griffith, 2008).

Hayes et al., (2003) indicated that food may be contaminated by polluted water, insects e.g. flies, rodents and pets, unclean utensils, dust and dirt (Gudeta, 2007). Equipment and containers that come into contact with food should be designed to enable easy cleaning and disinfection. The materials used for making the equipment should not have a toxic effect on food (Aarnisalo et al., 2006; Evans et al., 2004). Adequate facilities should be made available for the different core functions in food handling. The working area within the production area should be maintained clean to prevent contamination. All sinks, dish washing machines and other equipment should be so constructed to be easily cleaned and to be kept in good repair (Egan et al., 2007; Fuster et al., 2008).

Griffith et al., (2004) clarified that cross contamination is a very significant concept in food safety. Raw food, particularly meat, should be successfully separated, either physically or by time, from ready to eat and cooked foods, with transitional cleaning or disinfection where essential (Allwood et al., 2004; Green, and Selman, 2005).

\section{Aim and hypotheses of the study}

The study aims to explore the KAP model factors and their effect on hotel competitiveness among the food and beverage department staff. To achieve this aim, a number of research hypotheses were developed as follows: 


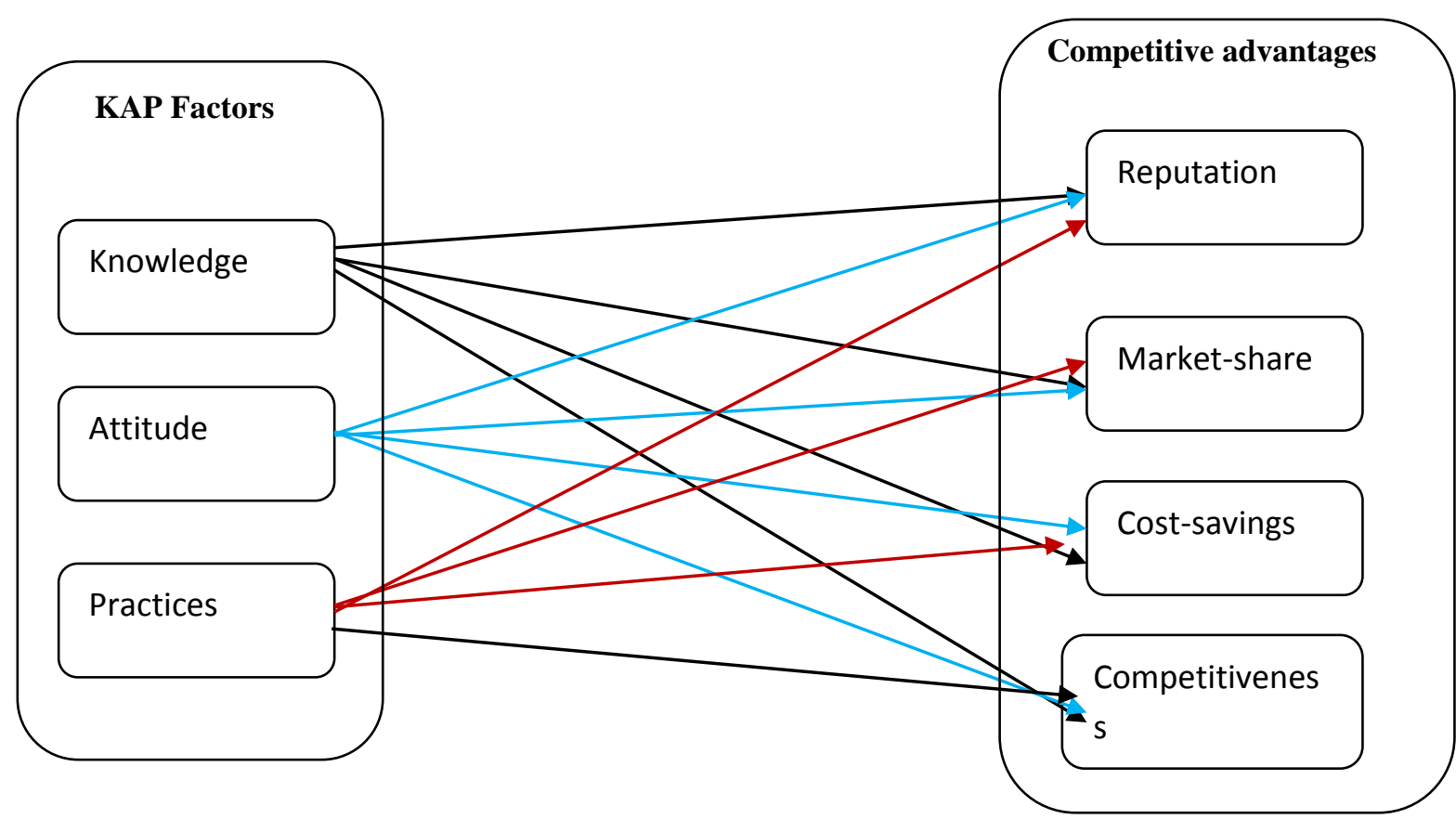

H1: Food and beverage staff perceive the gained knowledge, attitudes, and practices to have a significant effect on the hotel's reputation.

$\mathrm{H} 2$ : Food and beverage staff perceive the gained knowledge, attitudes, and practices to have a significant effect on the market share of the hotel.

H3: Food and beverage staff perceives the gained knowledge, attitudes, and practices to have a significant effect on cost savings.

H4: Food beverage staff perceives the gained knowledge, attitudes, and practices to have a significant effect on the competitiveness of the hotel.

\section{Literature review}

\section{Food, reputation and staff personal hygiene.}

Al-Dagal, (2003) ensured that good personal hygiene and sanitary handling practices at work are an essential part of any prevention program for food safety. Although the majority of the food and beverage department staff have the skills and knowledge to handle food safely, human handling errors have been implicated in most outbreaks of food poisoning (Sharif, and Al-Malki, 2010). Greig et al., (2007) indicated that the inappropriate handling of foods by the food service industry has been implicated in $97 \%$ of food poisoning cases.

Prianka et al., (2012) showed that food handlers should maintain a high level of personal cleanliness and wear suitable protective clothing, head gear and footwear. Tang, and Fong, (2004) also explained that People involved in food handling should refrain from smoking, spitting, chewing and sneezing or coughing over unprotected food. So, Food safety is dependent upon the significant roles played by food handlers along the food service system (Todd et al., 2010). Food handlers may introduce pathogenic microbes to the food during the process of preparation, distribution and serving (Green et al., 2007).

Improper food handling may be implicated in $97 \%$ of all food borne illness associated with catering outlets (Clayton, and Griffith, 2004). Improper practices responsible for microbial food borne illnesses have been well documented (Martins, 2012) and typically involve cross-contamination of raw and cooked foodstuffs, inadequate cooking and storage at improper temperatures.

Herztman, and Barrash, (2007) cleared that the food and beverage department staff may also be asymptomatic carriers of food poisoning organisms (Jianu, and Chis, 2012).

It is important to have an understanding of the interaction on prevailing food safety knowledge, attitudes and practices of food handlers in order to minimize food borne outbreaks (WHO, 2008). Food safety has been defined 


\section{The Effects of Food Safety Knowledge, Attitude and Practices on Hotel Competitive Advantages: Perceptions of Food Service Staff in Hotels}

as the conditions and measures that are necessary during the production, processing, storage, distribution and preparation of food to ensure that it is safe, sound, and wholesome and fit for human consumption (Dewaal, and Robert, 2005). Griffith et al., (2010) also propose a definition of food safety culture as the aggregation of the prevailing, relatively constant, learned, shared attitudes, values and beliefs contributing to the hygiene behaviours within a particular food handling environment.

\section{KAP Model in the food Industry}

Hubbard and Hayashi, (2003) mentioned that Rogers proposed DOI theory (Diffusion of Innovations) in 1962. This theory tries to describe the process by which new ideas, or new methods, spread over time (Lee, 2006). In recent years, scholars have been conducting empirical research on innovation diffusion theory, and have integrated the innovation adoptions into three stages: knowledge, attitude and practice (Hubbard \& Hayashi, 2003).

The learning knowledge of the learner affects his learning attitude, while learning attitude affects, and is shown through, the learner's behaviour (Wang et al., 2009). On one hand, KAP model had been employed in the hygiene education field from 1960's to teach patients how to correct their health behaviour in practice, cognitive learning focuses on the knowledge and the ability of realization; affective learning means to change subject's intention, attitude or norms to adjust themselves through hygiene education, the psychomotor learning focuses on cultivating learner's health behaviour (Nyi et al., 2007; Lothian, etal.,1996). On the other hand, educational field focus on cultivating student's cognitive, affective, and psychomotor, against KAP model in hygiene education field, $\mathrm{K}$ (knowledge) to cognitive, A (attitude) to affective, and $\mathrm{P}$ (practice) to psychomotor in educational field, the difference is that psychomotor require students learned some skills, compared with $\mathrm{P}$ (practice) which requires the changing of behaviour as target (Lin, 2001).

Conventional thinking in the field of education is that knowledge affects the learner's attitude directly, and the attitude is transformed into behaviour (Lee, 2006). Xie, (2003) ststes that if the student has a higher level of knowledge, his learning attitude will be relatively more positive. Other related studies find that knowledge will directly affect the attitude and practice, and that attitude will directly affect practice or intention, except that the degree of impacts of knowledge on practice through attitude is better than that of knowledge on practice directly (Li, 2002; Lin, 2001; Lee, 2006).

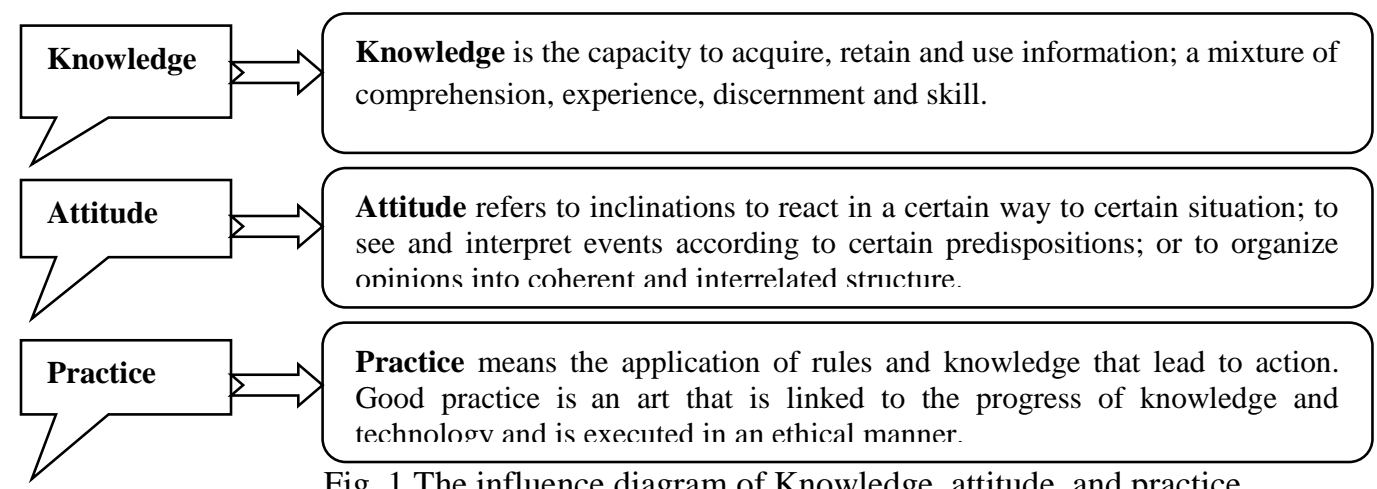

Fig. 1 The influence diagram of Knowledge, attitude, and practice

Food Safety Knowledge, Attitudes and Practices

Roberts et al., (2008) explained that training of food handler is seen as one strategy whereby food safety can be increased, offering long-term benefits to the food industry. Seaman, (2010) defined training as 'a planned process to modify attitude or skill behaviour through learning experience to achieve effective performance in an activity or a range of activities'. Evaluation is integral to the training cycle, providing feedback on the effectiveness of the methods used, checking the achievement of the objectives set by both the trainer and trainee and assessing whether the needs originally identified have been met (Acikel et al., 2008). Criteria that may be used for assessing the effectiveness of a training programme include reaction to training, knowledge acquisition, changes in job-related behaviour and performance and improvements of organisational-level results (Seaman, and Eves, 2010; Hine et al., 2003).

Seaman and Eves, (2010) agreed with Askarian et al., (2004) that the provision of knowledge to change food hygiene attitudes and behaviours has not been adequately proven in literature. An effective food-training course should not only provide food hygiene information, but it should implement knowledge into practice for proper information retention. 
(Cecilia et al., 2007). Three factors are playing a major role in the occurrence of food contamination with regard to the food and beverage department staff represented in knowledge, attitude and practice (Sharif \& Al-Malki, 2010). Training programs are important for improving the knowledge of the cuisine staff; however, more knowledge of food hygiene practices does not always lead to positive changes in food handling behaviours (Ansari et al., 2010). Because of this,

\section{Knowledge items}

\section{Researchers}

various parts of the world (Bas et al., 2006; Martins et al., 2012; Seaman and Eves, 2010).

Food safety knowledge many studies on the knowledge, attitudes and practices of the food and beverage department staff have been conducted in 


\section{The Effects of Food Safety Knowledge, Attitude and Practices on Hotel Competitive Advantages: Perceptions of Food Service Staff in Hotels}

\section{Personal Hygiene}

Smoking, spit, wear excessive jewellery, touches mouth, and pick nose is prohibited in the kitchen.

Wearing protective cloth while handling food reduces the risk of food contamination.

Washing hands before work reduces the risk of food contamination.

Eating and drinking in the work place increase the risk of food contamination.

During infectious disease of the skin, it is necessary to take leave from work.

Microbes are in the skin, nose and mouth of healthy handlers.

Dealing with approved suppliers.

Washing hands after coughing or sneezing.

Medical screening and exclusion of infected food handlers.

\section{Cross Contamination}

Cross contamination is when microorganisms from a contaminated food are transferred by the food handler's hands or kitchen utensils to another food.

Ready to eat food contaminated if not handled properly.

Contamination occurs when mix raw and ready to eat food.

Avoid bare hand contact with ready to eat food.

Damage merchandise should be rejected

Food prepared in advance reduces the risk of food contamination.

Salmonella, Hepatitis A virus, and Staphylococcus are among the food-borne pathogens.

FIFO method ensures earlier ordered foods are used first.

Proper bins with lids for food and other waste.
Seaman, and Eves, 2010; Greig et al., 2007; Martins et al., 2012; Wang et al., 2009.

Prianka et al., 2012; Herztman and Barrash, 2007.

Aarnisalo et al., 2006; Ansari et al., 2010.

Bas et al., 2006; Mcswane et al., 2004; Jianu, and Chis, 2012.

Cecilia et al., 2007; Ansari et al., 2010; Jianu, and Chis, 2012.

Green et al., 2007; Ansari et al., 2010; Jianu, and Chis, 2012

Ansari et al., 2010; Jianu, and Chis, 2012; Nyi et al., 2007.

Acikel et al., 2008; Ansari et al., 2010; Jianu, and Chis, 2012.

Clayton, \& Griffith, 2008; Xie, 2003; Ansari et al., 2010; Jianu, and Chis, 2012.

WHO, 2008; Jones and Angulo, 2006; Egan et al., 2007; Xie, 2003.

Garayoa et al., 2011; Ansari et al., 2010.

Wang et al., 2009; Todd et al., 2010.

Griffith et al., 2004; Fuster et al., 2008.

Dewaal and Robert, 2005; WHO, 2008

Jones and Angulo, 2006; Griffith et al., 2004

Evans et al., 2004; Herztman and Barrash, 2007; Sharif and Al-Malki, 2010.

Nyi et al., 2007; Griffith et al., 2004; Mcswane et al., 2004.

Todd et al., 2010; Ansari et al., 2010; Jianu and Chis, 2012.

Griffith et al., 2010; Egan et al., 2007.

Cold food should be below $5^{\circ} \mathrm{C}$. 
Hot food should be above $63^{\circ} \mathrm{C}$.

The temperature danger zone for potentially hazardous foods is $5^{\circ}$ to $63^{\circ} \mathrm{c}$.

Freezing kills all bacteria that may cause food-borne illness.

Cooking should be above $75^{\circ} \mathrm{C}$.

Reheating cooked food can contribute to food contamination.

\section{Sanitizing}

Cleaning is the systematic application of energy to a surface or substance with the intention of removing dirt.

Proper cleaning and sanitization of utensils decrease the risk of food contamination.

Clean is the same as sanitized.

Washing utensils with detergent leaves them free of Fuster et al., 2008; Wang et al., 2009; Ansari et contamination.

Following clean as you go policy.
Sharif and Al-Malki, 2010; Ansari et al., 2010.

Fuster et al., 2008; Dewaal and Robert, 2005; Martins et al., 2012.

Nyi et al., 2007; Egan et al., 2007.

Xie, 2003; Garayoa et al., 2011.

Wang et al., 2009; Herztman and Barrash, 2007. Egan et al., 2007; Herztman and Barrash, 2007.

Martins et al., 2012; Nyi et al., 2007; Jianu anc Chis, 2012.

Griffith et al., 2010; Gudeta, 2007. al., 2010; Xie, 2003.

Sharif and Al-Malki, 2010; Mcswane et al., 2004.

\section{Hotel reputation, competitive advantages, satisfaction, and loyalty}

Hotel reputation from the perspective of a customer is the extent to which a hotel is honest and committed to the customer's welfare (Boo, 2003). Moreover, because reputation shapes customers' expectations before they patronize a business, a good reputation suggests that the customer will expect the hotel's products/services to be of high quality, which is a direct antecedent to customer satisfaction(Novikova, 2009).

Furthermore, high-reputation companies are likely to gain customer trust because a good reputation can strengthen customer confidence and reduce the perception of risk when customers evaluate the organizational performance and the quality of the hotel's products/services (Liu, 2012, Abd-El-Salam E. et al., 2013). Regarding the relationship between perceived trust and customer satisfaction, some studies have examined the effect of customer satisfaction on customerperceived trust; other researches have demonstrated that customer-perceived trust is the antecedent of customer satisfaction(Novikova, 2009).

Kinzey (2013) built on previous research and concluded that a perceived value can generally be defined as "a judgment or a valuation by the customers of the comparison between the benefits or utility obtained from a product, service or relationship, and the perceived sacrifices or costs." Although customer-perceived value comprises multidimensional constructs, elements such as the cost of service continues to be important to customer evaluations (Torres, 2012, Xin and Fan, 2013).

Though customer loyalty can be manifested in multiple ways, such as by "expressing a preference for a company over others, by continuing to purchase from it, or by increasing business with it in the future", customer satisfaction is thought to be an important antecedent of customer loyalty (Novikova, 2009, Park et al., 2014).

\section{Methodology}

The current study is based on quantitative approach to achieve its aim. Data were collected by a semi-structured questionnaire from different food and beverage department staff at 33 Five-star hotels in Cairo. The obtained data was analysed using SPSS version 22. The total population of the study was 9333 (The Central Agency for Public Mobilization and Statistics, 2013) but the food and beverage department' staff (2790 nearly) were selected for sampling .The sample size was calculated according to the following formula: 


\section{The Effects of Food Safety Knowledge, Attitude and Practices on Hotel Competitive Advantages: Perceptions of Food Service Staff in Hotels}

$\mathrm{N}=$ Study Population $=2790$

$\mathrm{Z}=0.95=1.96$

$\mathrm{d}=0.05$

$$
n=\frac{N \times p(1-p)}{\left.\left[N-1 \times\left(d^{2} \div z^{2}\right)\right]+p(1-p)\right]}
$$

$\mathrm{p}=0.50$

$\mathrm{n}=325$

The sample size formula revealed a number of 325 staff member. A simple random sample of 350 five-star hotel employees was selected. A modified questionnaire (modified from Ansari et al., 2010; Jianu, and Chis, 2012) was designed to explore the KAP model among the food and beverage department staff that have a critical effect on hotels' competitive advantages.

The investigation of food safety knowledge, attitudes and practices in the hotel foodservice was carried out using multiple sources of data, including the semi-structured questionnaire, observations of the business environment, and a review of documentation.

\section{Questionnaire}

The questionnaire was organized as the follows: part 1: demographic information (such as gender, age, level of education, length of employment and participation in training); part 2: knowledge about food safety; part 3: attitudes on food safety; part 4: food hygiene practices; and part 5: hotel reputation.

The knowledge section (part 2) included 30 close-ended questions with five possible answers, "strongly agree", "agree", "neutral", "disagree", and "strongly "disagree". These questions focused on issues regarding personal hygiene, cross contamination, diseases carried by food, microorganisms, temperature control and hygiene practices. This scale ranged between 1 and 5 points.

The attitude section of the questionnaire (part 3) aimed to determine the understanding of the handler about food safety and contained 25 questions that required five levels of answers, "strongly agree", "agree", "neutral", "disagree", and "strongly "disagree".

In section 4, the good hygienic practices of the food and beverage department staff were evaluated and through 29 questions with five levels of answers, "never", "seldom", "sometimes", "often", and "always"; We used the same criterion as that used for the other parts, handlers who answered 4 or more questions correctly were regarded as good practices.

Section 5: Contained 4 questions of five levels of answers, "Strongly Agree", "Agree", "Neutral", "Disagree", and "Strongly "Disagree".

\section{Pilot Test}

The questionnaire was pre-tested by 5 experts who work in foodservice and academic field to check its validity. All experts were asked to complete the questionnaire and to identify concerns and suggestions. All suggestions had been considered before data collection.

\section{Statistical analysis}

Statistical analyses were performed using the Statistical Package for Social Sciences (version 22.0, SPSS,) software. Means, standard deviation and percentages were calculated for the scores from the cuisine staff knowledge, attitudes and practices sections. Chi square correlation was used to explore the correlation between food safety (KAP) model and hotel competitiveness. Statistical results were considered significant at $\mathrm{p} \leq 0.05$.

\section{Results and Discussion}

The analysis of the next questions will be ranked according to the objectives of the study as follows:

\section{Questionnaire Reliability Analysis}


Reliability was tested by Cronbach's alpha coefficient. The result for all the variables was acceptable (76.25).

\section{Questionnaire Response Rate}

A total of 263 usable replies out of 350 were obtained, representing an effective response rate of 75 percent.

\section{Questionnaire Analysis Results and Discussion}

\section{Demographic Characteristic of The respondents}

Table 1 demonstrates the demographic data of respondents. Out of the 263 respondents involved in this study, $82.1 \%$ were men, $17.9 \%$ were women; $52.5 \%$ of the participants were 36 to 55 years old. The education level of more than half of the respondents $(52.9 \%)$ were of middle school compared with high school $47.1 \%$. (29.7\%) of the respondents had less than five years of working experience, $23.6 \%$ have been in this sector for five to ten years, $34.6 \%$ for ten to 15 years and $12.2 \%$ for more than 15 years of experiences. About $64.3 \%$ of participants reported to have participated in food hygiene training programs over the past 12 months and $12.2 \%$ of participants had attended food safety training courses more than 3 times.

Table 1. Demographic characteristics of the respondents

\begin{tabular}{|c|c|c|c|}
\hline Characteristics & Demographic characteristic & Number & $(\%)$ \\
\hline \multirow{2}{*}{ Gender } & Male & 216 & 82.1 \\
\hline & Female & 47 & 17.9 \\
\hline \multirow{4}{*}{ Age (years) } & $<25$ & 0.00 & 0.00 \\
\hline & $25-35$ & 93 & 35.4 \\
\hline & $36-55$ & 138 & 52.5 \\
\hline & $>56$ & 32 & 12.2 \\
\hline \multirow{3}{*}{ Education Status } & Elementary school & 0.00 & 0.00 \\
\hline & Middle school & 139 & 52.9 \\
\hline & High school or higher education & 124 & 47.1 \\
\hline \multirow{4}{*}{ Working Experience } & Less than five years & 78 & 29.7 \\
\hline & 5 to 10 years & 62 & 23.6 \\
\hline & 10 to 15 years & 91 & 34.6 \\
\hline & More than 15 years & 32 & 12.2 \\
\hline \multirow{3}{*}{$\begin{array}{l}\text { Number of food safety training session's } \\
\text { received (last } 12 \text { months) }\end{array}$} & 0 & 62 & 23.6 \\
\hline & $1-2$ & 169 & 64.3 \\
\hline & $3-4$ & 32 & 12.2 \\
\hline Occupation & Food and Beverage & 125 & 47.5 \\
\hline
\end{tabular}




\section{The Effects of Food Safety Knowledge, Attitude and Practices on Hotel Competitive Advantages: Perceptions of Food Service Staff in Hotels}

\begin{tabular}{|l|c|c|c|}
\hline Characteristics & Demographic characteristic & Number & ( \% ) \\
\hline \multirow{2}{*}{} & Banquet & 0.00 & 0.00 \\
\cline { 2 - 4 } & Food production area & 138 & 52.2 \\
\hline
\end{tabular}

Food Safety Knowledge

Table 2. Food Safety Knowledge

Items of Personal Hygiene Knowledge.

Std.

Mean Deviation

\section{Personal Hygiene}

Smoking, spit, wear excessive jewellery, touches mouth, and pick nose is prohibited in the

kitchen.

Wearing protective cloth while handling food reduces the risk of food contamination.

Washing hands before work reduces the risk of food contamination.

Eating and drinking in the work place increase the risk of food contamination.

During infectious disease of the cuisine staff, it is necessary to take leave from work.

Microbes are in the skin, nose and mouth of healthy handlers.

Dealing with approved suppliers.

Washing hands after coughing or sneezing.

Medical screening and exclusion of infected food handlers.

$\boldsymbol{*} \mathbf{1 =}$ Strongly Disagree $\quad \mathbf{2}=$ Disagree $\quad \mathbf{3}=$ Neutral $\quad \mathbf{4}=$ Agree $\quad \mathbf{5}=$ Strongly Agree

The results in table (2) show that the largest mean is (4.46), and this value is closer to the agreeable value, which indicates that food handlers believe that Washing hands before work reduces the risk of food contamination. The results also indicate that the smallest mean is (2.25), and this value is closer to the disagreeable value, which illustrates that five star hotels in Cairo do not hold medical screening and exclusion of infected food handlers.

Additionally, the results indicate that the overall average of personal hygiene knowledge is (4.03), indicating fair knowledge among food handlers about personal hygiene.

This finding is consistent with previous studies conducted by Seaman, and Eves, (2010) who mentioned that the hotel management should make sure that food handlers are knowledgeable about personal hygiene rules. In addition, Smoking, spitting, wearing excessive jewellery, touching mouth, and picking nose are prohibited in the kitchen (Martins et al., 2012; Wang et al., 2009). Similarly Prianka et al., (2012) agreed with Herztman and Barrash, (2007) that Wearing protective clothes while handling food and Washing hands before work reduce the risk of food contamination. Generally Jianu, and Chis, (2012) assured that Medical screening and exclusion of infected food handlers improve the food safety issue.Regarding dispersion in the responses of respondents concerning this issue, the Standard Deviation showed no dispersion among the groups, indicating that they answered this question in the same way. 


\section{Cross Contamination}

Cross contamination is when microorganisms from a contaminated food are transferred by the

Salmonella, Hepatitis A virus, and Staphylococcus are food-borne pathogens.

Proper bins with lids for food and other waste.

\begin{tabular}{ll}
\hline Average Mean & 3.96 \\
\hline
\end{tabular}

*1= Strongly Disagree $\quad \mathbf{2}=$ Disagree $\quad \mathbf{3}=$ Neutral $\quad \mathbf{4}=$ Agree $\quad \mathbf{5}=$ Strongly Agree

The results in table (3) that the largest mean is (4.94), which indicates that the majority of food handlers know the cross contamination concept, the smallest mean is (1.88), illustrating that food handlers do not know that Salmonella, Hepatitis A virus, and Staphylococcus are food-borne pathogens. The overall average of Cross Contamination is (3.96), which indicates adequate knowledge among food handlers about food contamination and its control. And this finding is in line with Garayoa et al., (2011) and agrees with WHO,(2008).

Table 4. Time and Temperature control

\begin{tabular}{lccc}
\hline \multicolumn{1}{c}{ Items of Time and Temperature control. } & Mean & $\begin{array}{c}\text { Std. } \\
\text { Deviation }\end{array}$ \\
\hline Time and Temperature control & & \\
\hline Cold food should be below $5^{\circ} \mathrm{C}$. & 4.26 & 0.674 \\
Hot food should be above $63^{\circ} \mathrm{C}$. & 1.86 & 0.754 \\
The temperature danger zone for potentially hazardous foods is $5^{\circ}$ to $63^{\circ} \mathrm{C}$. & 3.88 & 1.040 \\
Freezing kills all bacteria that may cause food-borne illness. & 2.11 & 0.988 \\
Cooking should be above $75^{\circ} \mathrm{C}$. & 3.98 & 0.865 \\
Reheating cooked food can contribute to food contamination. & 2.11 & 0.988 \\
\hline
\end{tabular}




\section{The Effects of Food Safety Knowledge, Attitude and Practices on Hotel Competitive Advantages: Perceptions of Food Service Staff in Hotels}

\begin{tabular}{l} 
Average Mean \\
\hline$* \mathbf{1}=$ Strongly Disagree $\quad \mathbf{2}=$ Disagree $\quad \mathbf{3}=$ Neutral $\quad \mathbf{4 =}$ Agree $\quad \mathbf{5 =}$ Strongly Agree
\end{tabular}

The results table (4) show that the grand mean is (4.26), which indicates that food handlers are aware that cold food should be below $5^{\circ} \mathrm{C}$; the smallest mean is (1.86), which illustrates that food handlers have not adequate knowledge about Hot food should be served above $63^{\circ} \mathrm{C}$. The results also indicate that the overall average of Time and Temperature control knowledge is (3.97); this value indicates adequate knowledge among food handlers about Time and Temperature control.

Table 5. Sanitizing Knowledge

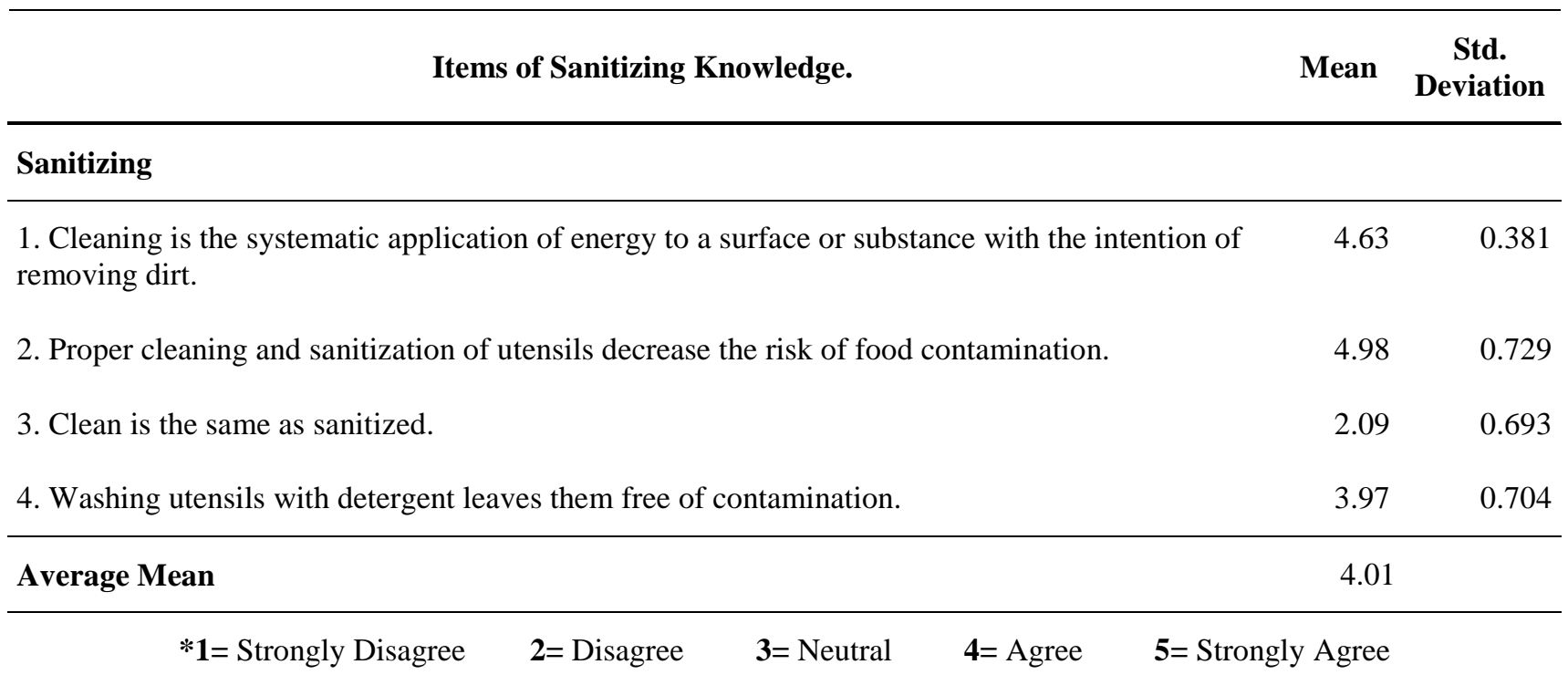

The results in table (5) show that the grand mean is (4.98), which indicates that the majority of food handlers know that proper cleaning and sanitization of utensils decrease the risk of food contamination. The results also indicate that the smallest mean (2.09), illustrates that food handlers know that Clean is not the same as sanitized. Additionally, the results indicate that the overall average of cleaning and Sanitizing is (4.01), indicating adequate knowledge among food handlers about cleaning and sanitizing management and this finding is in line with Garayoa et al., (2011). 
Mean $\begin{gathered}\text { Std. } \\ \text { Deviation }\end{gathered}$

I think sanitation is an important part of my job responsibilities.

I believe that good employee hygiene can prevent food borne illness.

4.02

0.774

I think that it is the responsibility of all food handlers to ensure that food is safe to serve.

I am willing to change my food handling behaviours when I know they are incorrect.

4.04

0.753

I am willing to obtain more food safety knowledge.

4.01

0.731

It is more important to have tasty food rather than safe food.

1.68

0.708

I select a place to eat based on its reputation for good sanitation and cleanliness.

1.83

0.714

I think that managers should educate employees on personal hygiene and sanitation regularly.

I think that only full-time employees should receive food safety training.

1.67

0.704

I believe that food safety knowledge not only benefits my work but also my personal life.

4.00

0.728

I am willing to attend a food safety training course.

4.92

I believe that food safety knowledge would make me more confident of my work.

I believe that cleaning supplies should be stored separately to prevent food contamination.

I think that food obtained from reliable and approved suppliers prevents food contamination.

5.00

I believe that Wearing protective cloth is an important practice to reduce the risk of food contamination.

I think the health status of workers should be evaluated before employment.

I believe that Monitoring temperature of raw and cooked food are vital.

I believe that Temperature Control is an effective method of reducing the number of cases of food poisoning.

I believe that previously cooked food must be reheated.

I think that checking internal temperature of food is very important.

I believe that smoking should be prohibited in food preparation area.

I think that Food contact surface should be cleaned using sanitizing agent.

I think that Food room cleanliness monitoring system provides good feedback for improvement. 


\section{The Effects of Food Safety Knowledge, Attitude and Practices on Hotel Competitive Advantages: Perceptions of Food Service Staff in Hotels}

The results in table (6) reveal that the grand mean is (5.00), which indicates that food handlers know that food obtained from reliable and approved suppliers prevents contamination. The results also indicate that the smallest mean (1.67), illustrates that food handlers believe that Temperature Control is an effective method of reducing the number of cases of food poisoning.

Additionally, the results indicate that the overall average of food safety attitudes is (3.97); this value indicates a good attitudes among food handlers to food safety. So, Prianka et al., (2012) showed that the hotel management should make sure those food handlers have good food safety attitudes. Regarding dispersion in the responses of respondents to this issue, the Standard Deviation showed no dispersion among the groups.

\section{Food Safety Practices}

Table 7. Food Safety Practices

\begin{tabular}{|c|c|c|}
\hline Items of Food Safety Practices. & Mean & $\begin{array}{l}\text { Std. } \\
\text { Deviation }\end{array}$ \\
\hline I use gloves or utensils to handle food that is ready-to-eat. & 4.69 & .654 \\
\hline I wash my hands properly before using gloves. & 4.90 & .331 \\
\hline I use a separate clean utensil for each food item. & 4.76 & .616 \\
\hline I use the same chopping boards to prepare raw food and cooked food. & 1.43 & .092 \\
\hline I use water proof plaster when get injured. & 4.56 & 1.054 \\
\hline I wash my hands thoroughly with soap and water before working with food. & 4.78 & .615 \\
\hline I wash raw produce before using it. & 4.89 & .439 \\
\hline I use a handkerchief when coughing. & 4.88 & .357 \\
\hline I store chemicals in a non-food storage room. & 4.84 & .448 \\
\hline I store raw food items in an area separate from cooked food. & 4.81 & .529 \\
\hline I wear a clean uniform, when I work in foodservice. & 4.82 & .550 \\
\hline I wear a mask when I have the flu & 4.57 & 1.023 \\
\hline I wear a hair restraint (cap or hairnet), when I work in foodservice. & 4.74 & .689 \\
\hline $\begin{array}{l}\text { I wash my hands and change into a new pair of gloves after touching anything that may } \\
\text { contaminate my hands, when I prepare or serve food. }\end{array}$ & 4.25 & 1.540 \\
\hline I drink or eat food while I am serving or preparing food & 2.20 & .837 \\
\hline I clean and sanitize work surfaces after each task. & 4.82 & .609 \\
\hline When I am in doubt about the safety of a previously cooked food, I report it to the supervisor. & 4.79 & .589 \\
\hline I pay attention to shelf life on foods and do not use foods that have passed the expiration date. & 4.84 & .550 \\
\hline
\end{tabular}


I check concentrations of sanitizing solutions used for sanitizing work surfaces or items washed in the pot and pan sink.

I continue to work on a sick day.

I Keep watch while working because time is precious for you.

I do not cover your head when my hair is neatly combed.

I wear the same apron as long as it looks clean.

I taste the food with your hand cupped.

I thaw food outside the refrigerator (i.e., room temperature).

I check the internal temperature of meat with a thermometer.

I use cutting boards of different colours or sanitize a cutting board between preparation of raw foods and cooked foods.

$* \mathbf{1}=$ Never $\quad 2=$ Seldom $\quad 3=$ Sometimes $\quad 4=$ Often $\quad 5=$ Always

Table (7) shows that the grand mean (4.90), indicates that food handlers always wash their hands properly before using gloves. The results also indicated that the smallest mean (1.20), illustrates that food handlers seldom taste the food with their hand cupped.

Additionally, the results indicate that the overall average of food safety practices variable is (3.90), indicates good practice among food handlers concerning food safety.

\section{Drivers of KAP Model Adoption}

Table 8. Drivers of KAP Model Adoption

\section{Drivers of KAP Model Adoption.}

Std.

Mean Deviation

Cost savings in the hotel.

$4.19 \quad 0.835$

Increasing market share.

$4.17 \quad 0.815$

Is a competitive advantage.

$4.48 \quad 0.833$

Positive impact on the hotel's reputation.

4.25

0.769

\begin{tabular}{ll}
\hline Average Mean & \\
\hline$* \mathbf{1}=$ Strongly Disagree $\quad \mathbf{2}=$ Disagree $\quad \mathbf{3}=$ Neutral $\quad$ 4= Agree $\quad \mathbf{5 =}$ Strongly Agree
\end{tabular}


The results (Table 8) indicate that the overall average of KAP model adoption drivers is (4.27), and this value indicates that the majority of food handlers believe that adoption of KAP model has an effective role in reducing production cost, creating sustainable competitive advantage, increasing market-share, and influencing on the hotel's reputation.

Regression analysis of KAP factors effect on hotels' reputation

Table 9. Good KAP effect on hotels' reputation

Coefficients $^{\text {a }}$

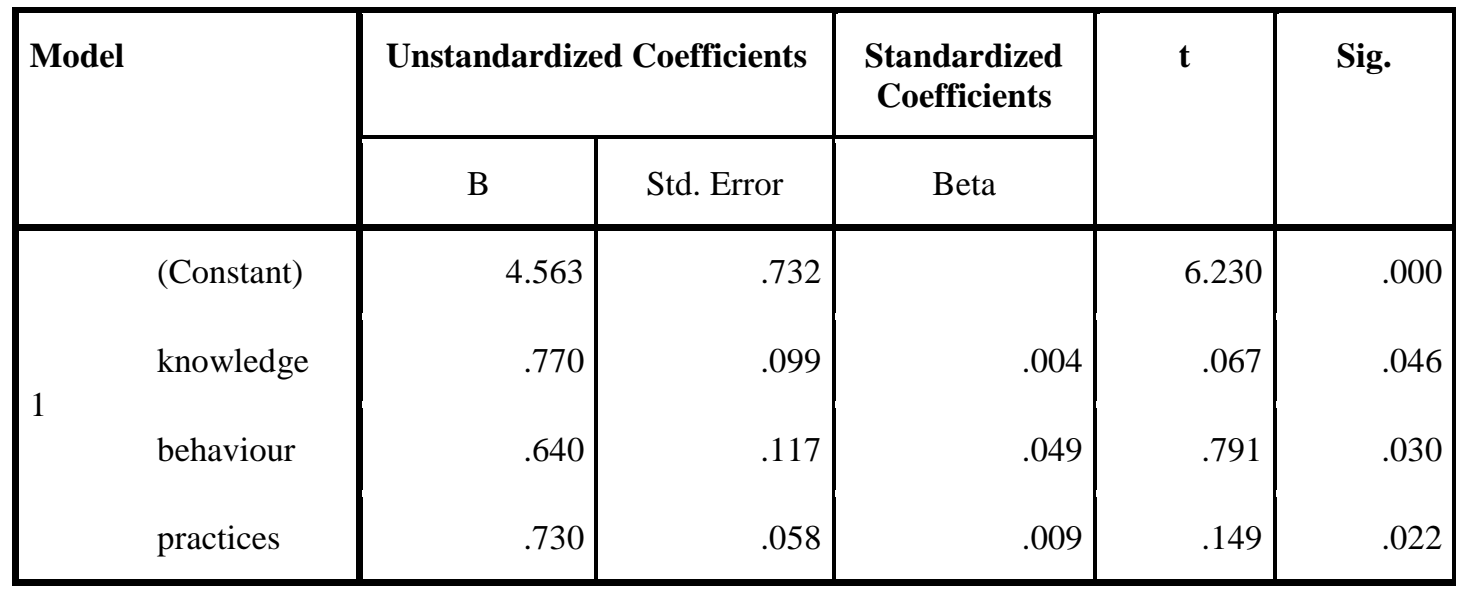

a. Dependent Variable: hotel reputation

The respondents perceive 3 variables to have a positive effect on the reputation of the hotel. The knowledge variable is positively affecting the hotel reputation $(\beta=-0.770$ and $\mathrm{p}<0.05)(\mathrm{H} 1)$. Furthermore, the behaviour is found positively affecting the reputation of the hotel $(\beta=0.640$ and $\mathrm{p}<0.05)(\mathrm{H} 1)$, and 50 practices $(\beta=0.730$ and $\mathrm{p}<0.01)(\mathrm{H} 1)$. These three variables (knowledge, behaviour, and practices) explain $58 \%$ of variance in hotel reputation $\left(\mathrm{R}^{2}=0.58\right)$. These results agree withMiller,( 2003), Chun,( 2005)

4.3.7 Regression analysis of good KAP effect on hotel market-share

Table 10 Good KAP effect on hotel market-share

\begin{tabular}{|c|c|c|c|c|c|}
\hline \multirow[t]{2}{*}{ Model } & \multicolumn{2}{|c|}{ Unstandardized Coefficients } & \multirow{2}{*}{$\begin{array}{c}\begin{array}{c}\text { Standardized } \\
\text { Coefficients }\end{array} \\
\text { Beta }\end{array}$} & \multirow[t]{2}{*}{$\mathbf{t}$} & \multirow[t]{2}{*}{ Sig. } \\
\hline & B & Std. Error & & & \\
\hline (Constant) & 5.392 & .852 & & 6.327 & .010 \\
\hline knowledge & .740 & .115 & .040 & .646 & .019 \\
\hline behaviour & .640 & .137 & .007 & .105 & .037 \\
\hline practices & .790 & .067 & .046 & .737 & .042 \\
\hline
\end{tabular}

a. Dependent Variable: increasing hotel market-share 
The respondents perceive 3 variables to have a positive effect on the hotel market-share. The knowledge variable is positively affecting the hotel market-share $(\beta=-0.740$ and $\mathrm{p}<0.05)(\mathrm{H} 2)$. Furthermore, the behaviour is found positively affecting the hotel market-share $(\beta=0.640$ and $p<0.05)(\mathrm{H} 2)$, and practices positively affect the hotel market-share $(\beta=0.790$ and $p<0.01)(\mathrm{H} 2)$. Those three variables (knowledge, behaviour, and practices) explain $56 \%$ of variance in the hotel market-share $(\mathrm{R} 2=0.56)$. These results agree with Becker et al.,( 2013)

\section{Regression analysis of good KAP effect on cost savings in hotels}

Table 11. Good KAP effect on cost savings in hotels

\begin{tabular}{|c|c|c|c|c|c|}
\hline \multirow[t]{2}{*}{ Model } & \multicolumn{2}{|c|}{ Unstandardized Coefficients } & \multirow{2}{*}{$\begin{array}{c}\begin{array}{c}\text { Standardized } \\
\text { Coefficients }\end{array} \\
\text { Beta }\end{array}$} & \multirow[t]{2}{*}{$\mathbf{t}$} & \multirow[t]{2}{*}{ Sig. } \\
\hline & B & Std. Error & & & \\
\hline (Constant) & 7.580 & 1.380 & & 5.494 & .032 \\
\hline knowledge & .790 & .186 & .072 & 1.176 & .018 \\
\hline behaviour & .670 & .221 & .139 & 2.253 & .025 \\
\hline practices & .740 & .109 & .066 & 1.058 & .041 \\
\hline
\end{tabular}

a. Dependent Variable: cost savings

The respondents perceive 3 variables to have a positive effect on reducing the production cost in hotels. The knowledge variable $(\beta=-0.790$ and $p<0.05)(H 3)$; behaviour $(\beta=0.670$ and $p<0.05)(H 3)$, and practices $(\beta=0.740$ and $p<0.01)(H 3)$. These three variables explain $53 \%$ of variance in the production cost in hotels $(\mathrm{R} 2=0.53)$. These results agree with Torres, (2012)

\section{Regression analysis of good KAP effect on the competitiveness for the hotels}

Table 12. Good KAP effect on the competitiveness for the hotels.

\begin{tabular}{|c|c|c|c|c|c|}
\hline \multirow[t]{2}{*}{ Model } & \multicolumn{2}{|c|}{ Unstandardized Coefficients } & \multirow{2}{*}{$\begin{array}{c}\begin{array}{c}\text { Standardized } \\
\text { Coefficients }\end{array} \\
\text { Beta }\end{array}$} & \multirow[t]{2}{*}{$\mathbf{t}$} & \multirow[t]{2}{*}{ Sig. } \\
\hline & B & Std. Error & & & \\
\hline (Constant) & 5.545 & .864 & & 6.420 & .000 \\
\hline knowledge & .590 & .116 & .031 & .507 & .013 \\
\hline behaviour & .670 & .139 & .021 & .337 & .025 \\
\hline practices & .420 & .068 & .130 & .083 & .038 \\
\hline
\end{tabular}

a. Dependent Variable: competitive advantage

Three variables have a positive effect on the competitive advantage for the hotels:The knowledge variable $(\beta=-0.590$ and $\mathrm{p}<0.05)(\mathrm{H} 4)$; behaviour $(\beta=0.670$ and $\mathrm{p}<0.05)(\mathrm{H} 4)$, and practices $(\beta=0.420$ and $\mathrm{p}<0.01)(\mathrm{H} 4)$. These three variables explain $51 \%$ of variance in the competitive advantage for the hotels $(\mathrm{R} 2=0.51)$. These results agree with Loo and Davies, (2006) Abd-El-Salam E. et al., (2013). 


\section{The Effects of Food Safety Knowledge, Attitude and Practices on Hotel Competitive Advantages: Perceptions of Food Service Staff in Hotels}

\section{Recommendations for food and beverage managers at five-star hotels in Cairo, based on results of this study include:}

- Implementing an efficient food safety-training program for food and beverage department staff to ensure all food handlers have appropriate levels of food safety knowledge and positive attitudes, and demonstrate these in practice.

- Developing a checklist to ensure all food safety components are covered during food safety orientation and training.

\section{Directions for future research}

This study has several limitations, which affect the generalizability of the results and suggest the possibilities for future research. Throughout the research, several methodological decisions had to be made, such as choice of the theory, conceptual frame of reference, sample, and data collection and data analysis methods. Each of these decisions either implies some limitations or raises the question of how the choice of another research strategy would have affected the results. However, since the conclusions of previous studies back up what has been found here, it can be claimed that the study findings are somewhat generalizable.

\section{References}

Aarnisalo, K., Tallavaara, K., Wirtanen, G., Maijala, R. \& Raaska, L., (2006), "The hygienic working practices of maintenance personnel and equipment hygiene in the Finnish food industry", Food Control, 17, 1001-1101.

ABD-EL-SALAM E., SHAWKY A. \& EL-NAHAS T. 2013. The impact of corporate image and reputation on service quality, customer satisfaction and customer loyalty: testing the mediating role. Case analysis in an international service company The Business \& Management Review, Vol.3 Number-2, Arab Academy for Science and Technology and Maritime Transport, College of Management and Technology, Alexandria, Egypt.

Acikel, C. H., Ogur, R., Yaren, H., Gocgeldi, E., Ucar, M., \& Kir, T., (2008), "The hygiene training of the food and beverage department staffat a teaching hospital", Food Control, 19,186e190.

Al-Dagal, M., (2003), "Food safety knowledge and behaviour of Sanitarians of Riyadh Municipality (Saudi Arabia)", Food Protection Trends, 23(2), 142-148.

Allwood, P. B., Jenkins, T., Paulus, C., Johnson, L., \& Hedberg, C. W., (2004), "Hand washing compliance among retail food establishment workers in Minnesota", Journal of Food Protection, 67 (12), 2825-2828.

Ansari, M., Soodbakhsh, S. \& Lakzadeh, L., (2010), "Knowledge, attitudes and practices of workers on food hygienic practices in meat processing plants in Fars", Iran. Food Control, 21, 260-263.

Askarian, M., Kabir, G., Aminbaig, M., Memish, Z. \& Jafari, P., (2004), "Knowledge, attitudes, and practices of food service staff regarding food hygiene in Shiraz”, Iran. Infection Control Hospital Epidemiology, 25, 16-20.

Bas, M., Ersun, A. S., \& Kivanç, G., (2006), "The evaluation of food hygiene knowledge, attitudes, and practices of food handler's in food businesses in Turkey", Food Control, 17,317e322.

BECKER, K., NOBRE, H. \& KANABAR, V. 2013. Monitoring and protecting company and brand reputation on social networks: when sites are not enough. Global Business and Economics Review, 15, 293-308.

BOO, H. C. 2003. Brand alliance model: The moderating role of consumption goals and image congruency in consumers' hotel brand evaluations. $3106209 \mathrm{Ph} . D$., The Pennsylvania State University.

Cecilia, B., Alessandra, C., Santo, G., Marco, G., Maurizio, G. \& Gaterina, M., (2007), "Food safety in hospital: knowledge, attitudes and practices of nursing staff of two hospitals in Sicily", Italy. BMC Health Services Research,7.

CHUN, R. 2005. Corporate reputation: Meaning and measurement. International Journal of Management Reviews, 7 , 91-109.

Clayton, D. A. \& Griffith, C., (2004), "Observation of food safety practices in catering using notational analysis", 106:211-227. British Food Journal, 106, 211-227.

Clayton, D. A. \& Griffith, C., (2008), "Efficacy of an extended theory of planned behaviour model for predicting caterers'hand hygiene practices", International Journal of Environmental Health Research, 18, 83-98.

Dewaal, C. S., \& Robert, N. (2005). Global and Local: Food Safety Around the World. Washington D.C.: Center for Science in the Public Interest.

Egan, M., Rssts, M., Grubb, S., Eves, A., Lumbers, L., Dean, M. \& Adams, M., (2007), "A Review of food safety and food hygiene training studies in the commercial sector", Journal of Food Control, 18, 1180-1190.

Egyptian Hotel Guide 2011-2012., (2012), 32nd edition, Egypt: Egyptian Hotel Association.

Evans, J. A., Russell, S. L., James, C. \& Corry, J. E., (2004), "Microbial contamination of food refrigeration equipment", Journal of Food Engineering, 62, 225-232.

Fuster, N., Hernandez, M., Marine, M. \& Rodriguez, J., (2008), "Effect of different environmental conditions on the bacteria survival on stainless steel surfaces”, Food Control, 19, 308-314. 
Garayoa, R., Vitas, A. I., Diez-Leturia, M., \& Garcia-Jalon, I., (2011), "Food safety and the contract catering companies: the cuisine staff, facilities and HACCP evaluation", Food Control, 22, 2006-2012.

Green, L. R. \& Selman, C., (2005), “Factors impacting food workers' and managers' safe food preparation practices: a qualitative study", Food Protection Trends, Vol. 25 No. 12, 981-990.

Green, L., Radke, V. \& Mason, R., (2007), "Factors related to food worker hand hygiene practices", Journal of Food Protection, 70, 661-666.

Greig, J. D., Todd, E. C., Bartleson, C. A., \& Michaels, B. S., (2007), "Outbreaks where food workers have been implicated in spread of food borne disease, part 1.Description of the problem, methods, and agents involved", Journal of Food Protection, 70, 1752e1761.

Griffith, C. J.; Slader, J. and Humphrey , T . J., (2004)," microbiological and observational analysis of cross contamination risks during domestic food preparation", British food journal, Vol. 106, No. 8, pp. 581-597.

Griffth, C., Livesey, K. \& Clayton, D., (2010), "Food safety culture: The evolution of an emerging risk factor", British Food Journal, 112, 426-438.

Gudeta., D., (2007), "Sanitary Survey of Food and Drinking Establishments in Ambo Town West Showa Zone Oromia Region", MSc. Thesis, Addis Ababa University.

Hayes, C., Elliot, E., Krales, E. \& Drowner, G., (2003), "Food and water safety for persons infected with HIV", CID, 36, $106-109$.

Herztman, J. \& Barrash, D., (2007), “An assessment of food safety knowledge and practices of catering employees”, British Food Journal, 109(7), 562-576.

Hine, S., Thilmany, D., Kendall, P., \& Smith, K., (2003). "Employees and food safety: is training important to food service managers?" Journal of Extension, 41(1)

Hubbard, S. M., \& Hayashi, S. W., (2003), "Use of diffusion of innovations theory to drive a federal agency's program evaluation", evaluation and Program Planning, 26, 49-56. doi:10.1016/S0149-7189(02)00087-3.

Jianu, C., \& Chis, C., (2012), "Study on the hygiene knowledge of the food and beverage department staffworking in small and medium-sized companies in western Romania", Food Control, 26,151e156.

Jones, T. F. \& Angulo, F. J., (2006), "Eating in Restaurants: a risk factor for food borne disease", Clinical Infection Diseases, 43, 1324 -1328.

Kandampully, J. A., (2007), "Services Management: The New Paradigm in Hospitality", Upper Saddle River, New Jersey: Pearson Prentice Hall.

KINZEY, R. E. 2013. Promoting Nonprofit Organizations: A Reputation Management Approach, Routledge.

Lee, M. H., (2006), “A Study of Knowledge and Behavior of Elementary School Students' Green Consumption in Pingtung Country", Doctoral dissertation, National Pingtung University of Education, Pingtung Taiwan.

Li, S. Q., (2002), “The Impact of Family Factor on Family Green Consumption Tendency”, Doctoral dissertation, IShou University, Kaohsiung Taiwan.

Lin, Y. K., (2001), "A Study on the Knowledge, Attitude and Practice of Green Consumption on Adolescent and Youth", Doctoral dissertation, National Taiwan Normal University, Taipei Taiwan

LIU, Y. 2012. Digital trust and reputation: Applications and security issues. 3509755 Ph.D., University of Rhode Island.

LOO, T. \& DAVIES, G. 2006. Branding China: The ultimate challenge in reputation management? Corporate Reputation Review, 9, 198-210.

Lothian, S. F., Ferrence, R., \& Kaiserman, M. J., (1996), "Restrictions on smoking”, In Stephens, Morin, M. (eds.), Youth Smoking Survey, Technical Report, Ottawa: Minister of Supply and Services Canada.

Martins, R. B., Hogg, T., \& Otero, J. G., (2012), "The cuisine staff' knowledge on food hygiene: the case of a catering company in Portugal", Food Control, 23,184e190.

Mcswane, D., Rue, N. R., Linton, R. \& Williams, A. G., (2004), "Essentials of Food Safety and Sanitation: Food Safety Fundamentals", Upper Saddle River. New Jersey. Pearson Prentice Hall.

MILLER, B. M. 2003. Reputation management: A qualitative and quantitative analysis of the effective use of reputation management techniques when faced with crisis situations including the construction and validation of a media index for framing tones in crisis situations. 1415056 M.S.J., West Virginia University.

NOVIKOVA, K. 2009. A study of customer satisfaction factors and employee satisfaction in the hospitality industry. 1464981 M.S., Southern Illinois University at Carbondale.

Nyi, N., Maizun, Z., Wan, H., Hamzah, A. M., Noraidatulakma, A., \& Mohd Hilmi, A. B., (2007), "A study on effectiveness of health education program on knowledge, attitude and practice (KAP) of the food and beverage department staff towards food borne diseases and food safety", International Medical Journal, 14, 253-260.

PARK, J., KIM, H. J. \& MCCLEARY, K. W. 2014. The impact of top management's environmental attitudes on hotel companies' environmental management. Journal of Hospitality \& Tourism Research, 38, 95-115.

Payne-Palacio, J., \& Theis, M., (2012), "Foodservice Management Principles and practices”, (12th. Ed. ed.): Prentice Hall. 


\section{The Effects of Food Safety Knowledge, Attitude and Practices on Hotel Competitive Advantages: Perceptions of Food Service Staff in Hotels}

Prianka, M., Gautam, K., Kanad, B., Amrita, S., Sonali, S. \& Sesadri, K., (2012), "Indentifying key risk behaviours regarding personal hygiene and food safety practices of the food and beverage department staff working in eating establishments located within a hospital campus in Kolkata", Al Ammen journal of medical science, 5, $21-28$.

Roberts, K., Barrett, B., Howells, A., Shanklin, C., Pilling, V. \& Brannon, L., (2008), "Food safety training and foodservice employees' knowledge and behavior", Food Protection Trends, 28, 252-260.

Seaman, P., \& Eves, A., (2010), "Perceptions of hygiene training amongst the cuisine staff, managers and training providers qualitative study", Food Control, 21, 1037e1041.

Seaman, P., (2010), "Food hygiene training: introducing the food hygiene training model”, Food Control, $21,381 \mathrm{e} 387$.

Sharif, L., \& Al-Malki, T., (2010), "Knowledge, attitude and practice of Taif University students on food poisoning", Food Control, 21,55e60.

Tang, C., \& Fong, U., (2004), “A survey of food hygiene knowledge and attitudes among Chinese the food and beverage department staffing Fong Song Tong District", Journal of Public Health, 16(2), 120-124.

The Central Agency for Public Mobilization and Statistics, 2013. Annual Bulletin for the statistics of hotel and Resort activities. December.

Todd, E. C. D., Michaels, B. S., Smith, D., Greig, J. D., \& Bartleson, C. A., (2010), “Outbreaks where food workers have been implicated in the spread of food borne disease", Part 9. Washing and drying of hands to reduce microbial contamination. Journal of Food Protection, 73, 1937e1955

TORRES, E. N. 2012. Hotel general managers' use of consumer, expert, and internal feedback to improve service quality. 3544544 Ph.D., Purdue University.

Wang, P. W. , Huang, J. J. , Tang, H. L., Yeh, G. L. \& Tseng, C. C., (2009), “A Case Study on Knowledge, Attitude, and Behavioral Intention Related to Green Consumption and Related Factors for 7 (superscript) $\sim 9$ (superscript) Students on One School in Taipei City", Chinese Journal of Science Education, 17(3), 255-274.

World Health Organization, (2008), "WHO Initiative to Estimate the Global Burden of Food-borne Diseases: A Summary Document", Geneva. 2008.

World Health Organization. (2007).Food safety and food-borne illness. Fact sheet No. 23. Available athttp://wwwwho.int/mediacentre/factsheets/fs237/en/ (Reviewed March).

Xie, P. S., (2003), "A Case Study on Knowledge, Attitude, and Behavioral Intention Related to Green Consumption and Related Factors for High School Students on One School in Taipei County", Unpublished doctoral dissertation, National Taiwan Normal University, Taipei Taiwan.

XIN, L. \& FAN, Y. Framework of Reputation Aggregation Management for Service-Oriented Business Ecosystems. Service Sciences (ICSS), 2013 International Conference on, 2013. IEEE, 55-59. 